\title{
TINGKAT PEMAHAMAN MAHASISWA TERHADAP UPACARA ADAT NAIK DANGO MASYARAKAT DAYAK KANAYANT
}

\section{THE LEVEL OF STUDENTS' UNDERSTANDING ON NAIK DANGO CULTURE OF DAYAK KANAYANT SOCIETY}

\author{
Yosua Damas Sadewo ${ }^{1)}$, Pebria Dheni Purnasari ${ }^{2)}$, Sabinus Beni ${ }^{3)^{*}}$ \\ 1,2,3) STIM Shanti Bhuana, Bengkayang Kalimantan Barat \\ *email: yosua.damas@shantibhuana.ac.id
}

Diterima : 27 Maret 2020 ; Revisi : 26 Juni 2020 ; Diterbitkan 3 Agustus 2020

\begin{abstract}
The purpose of this study is to describe the understanding of STIM Shanti Bhuana students on Naik Dango Traditional Ceremony. This study applied a qualitative descriptive method. The result showed that the students understood Naik Dango well. Their understanding was perceived from the 3 indicators. They were the meaning of Naik Dango; the implementation of Naik Dango; and the functions of Naik Dango. Most respondents were aware that this traditional ceremony was an expression of gratitudes for the rice harvest to God. Besides, the implementation of Naik Dango Traditional Ceremony was an event to show the development various traditional arts. This event was not only an expression of gratitudes to God but also an attempt to strengthen the relationship among the communities.
\end{abstract}

Keywords: Level of Understanding, Traditional Ceremonies, Naik Dango, Dayak Kanayant

\section{ABSTRAK}

Tujuan dari peneletian ini untuk mendeskripsikan pemahaman mahasiswa STIM Shanti Bhuana terhadap Upacara Adat Naik Dango. Metode yang digunakan dalam penelitian ini adalah metode kualitatif deskriptif. Hasil penelitian menunjukkan pemahaman mahasiswa terhadap upacara Naik Dango cukup baik. Pemahaman mahasiswa mengenai tradisi adat Naik Dango ditinjau dari 3 aspek yakni aspek arti; aspek makna; aspek fungsi dan tujuan. Secara keseluruhan pemahaman mahasiswa pada Upacara Adat Naik Dango berada pada kategori cukup baik. Mayoritas generasi muda masyarakat Dayak Kanayant yang dijadikan responden menyadari bahwa upacara adat ini secara khusus dilakukan untuk ungkapan syukur atas panen padi atau pesta padi kepada sang Pencipta terhadap hasil panen padi yang telah diperoleh. Selain itu pelaksanaan dari Upacara Naik Dango juga telah mengalami perkembangan yakni dengan disisipinya berbagai kesenian adat. Hal ini juga turut mempengaruhi tujuan dari Upacara Adat Naik Dango yakni tidak sebatas ungkapan syukur kepada pencipta namun juga digunakan untuk mempererat hubungan antar masyarakat.

Kata kunci: Tingkat Pemahaman, Upacara Adat, Naik Dango, Dayak Kanayant

\section{PENDAHULUAN}

Adat istiadat merupakan bagian dari kebudayaan yang ada di Indonesia, dimana kebudayaan ini lahir dari berbagai tradisi suku-suku yang ada di Indonesia. Salah satu kegiatan adat yang masih sering digelar di Indonesia adalah upacara adat. Kamus Antropologi menjelaskan bahwa upacara merupakan suatu kegiatan pesta tradisional yang diatur menurut tata adat atau hukum yang berlaku dalam masyarakat untuk memperingati peristiwa penting berdasarkan ketentuan adat yang bersangkutan. Lebih lanjut (Saryana, 2003) menjelaskan bahwa upacara adat merupakan salah satu bentuk kebudayaan yang mempunyai arti penting bagi kehidupan di masyarakat. Di Indonesia terdapat berbagai jenis upacara adat. Salah satunya 
upacara adat Naik Dango yang menjadi tradisi bagi masyarakat Dayak khususnya, Dayak Kanayant. Tentu dengan dijaganya upacara adat ini, Naik Dango menjadi budaya tersendiri bagi suku Dayak Kanayant, sekaligus menjadi pembeda dengan suku lain yang ada di Indonesia. Dipandang dari suku, upacara adat yang merupakan satu kesatuan dalam budaya memang memiliki perpbedaan satu dengan yang lain. Namun, dalam kancah nasional kebudayaan-kebudayaan ini menjadi bagian dari kesatuan Republik Indonesia.

Dayak atau Daya merupakan kumpulan dari berbagai sub-etnik Austronesia yang dianggap sebagai penduduk asli yang mendiami Pulau Kalimantan. Hampir semua nama sebutan orang Dayak memiliki makna sebagai sesuatu hal yang berkaitan dengan "perhuluan" atau sungai, terutama pada nama-nama rumpun dan nama kekeluargaannya. Kelompok Suku Dayak terbagi kedalam sub-sub suku yang jumlahnya berkisar 450 subsuku dan tersebar di seluruh wilayah Kalimantan. Terbaginya suku Dayak kedalam berbagai sub-sub suku juga dipengaruhi oleh berbagai faktor.

Dalam sejarah, Suku Dayak pada mulanya berasal dari kelompok yang sama. Munculnya subsuku pada Suku Dayak dipengaruhi oleh faktor geografi dan demografi yang terus-menerus berlangsung hingga kelompok tersebut terpecah-pecah (Priskila, 2010). Tentunya karena geografi dan demografi, faktor tersebut mempengaruhi terbentuknya adat istiadat yang dimiliki tiap Subsuku Dayak.

Suku Dayak memiliki keberagaman seni dan budaya, seperti seni tari, seni pahat, seni lukis, budaya panen padi, dan lain sebagainya. Salah satu tradisi adat yang terkenal adalah Upacara Adat Naik Dango. Tradisi ini merupakan suatu upacara adat sebagai bentuk ucapan syukur atas hasil panen padi yang diterima oleh masyarakat suku Dayak. Wina \& Habsari (2017) menyebutkan bahwa dango dalam bahasa Dayak Kanayant memiliki arti sebagai lumbung yang berfungsi sebagai tempat menyimpan padi. Mintosih \& Widiyanto (1997) mengartikan Naik Dango sebagai upacara adat untuk memperingati penutupan dari rangkaian upacara yang berkaitan dengan kegiatan berladang khususnya tanam padi serta sebagai tanda bahwa kegiatan perladangan telah selesai dilaksanakan.

Tradisi Naik Dango diyakini berasal dari mitos asal mula padi yang dibawa oleh Nek Baruang Kulup (Ivo, 2001). Dalam mitos tersebut, dijelaskan bagaimana padi dikenal sebagai makanan pokok. Priskila (2010) menjelaskan bahwa dalam cerita Nek Baruang Kulup terdapat makna sendiri yakni, pekerjaan dan kehidupan seperti bertani, berladang, kelahiran, perkawinan, serta kematian dilakukan dengan mengikuti aturan-aturan dengan tujuan dapat saling menghormati satu dengan yang lainnya. Menurut Mintosih \& Widiyanto (1997), upacara Adat Naik Dango memiliki tujuan sebagai ungkapan rasa syukur masyarakat kepada Jubata (Sang pencipta) atas panen padi yang diperoleh. Ranubaya (2016) dan Ivo (2001) menjelaskan bahwa melalui upacara Naik Dango, suku Dayak Kanayant dapat merefleksikan kegiatan yang telah dilakukan dan sekaligus memanjatkan doa kepada Sang Pencipta sebagai bentuk ungkapan syukur dan permohonan, serta mempererat hubungan persaudaraan atau solidaritas.

Tradisi Naik Dango ini merupakan salah satu upacara adat yang terbuka; artinya masyarakat sekitar yang meskipun bukan suku Kanayant dijinkan melihat ritual 
Upacara Adat Naik Dango. Namun, pelaksananya tetap suku Dayak Kanayant. Ranubaya (2016) menjelaskan bahwa tahap-tahap pelaksanaan ritual Naik Dango sebagai berikut:

1. Persiapan sebelum pelaksanaan Persiapan yang dilakukan sebelum hari pelaksanaan antara lain dengan mengucapkan mantra (nyangahathn) yang disebut Matik. Kegiatan ini dilakukan untuk memberitahukan dan memohon restu pada Yang Kuasa.

2. Pelaksanaan

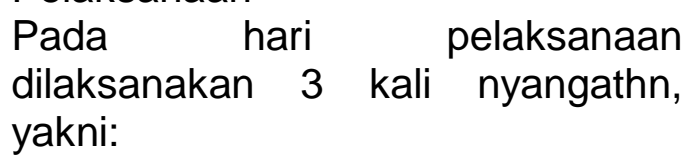

a. Pertama di Sami, tujuannya adalah untuk memanggil jiwa atau semangat padi yang belum datang agar datang kembali ke rumah adat.

b. Kedua di Baluh atau Langko, tujuannya untuk mengumpulkan semangat padi di tempatnya yakni, di lumbung padi.

c. Ketiga di Panderengan, tujuannya untuk memanjatkan doa agar beras terberkati sehingga dapat bertahan dan tidak cepat habis

Apabila dicermati dari beberapa pendapat di atas, pada dasarnya pelaksanaan dari Upacara Adat Naik Dango bermakna sebagai upacara yang dilakukan untuk memanjatkan doa atas karunia sekaligus permohonan berkat. Selain itu, Upacara Adat Naik Dango juga dapat menjadi pertanda dari berakhirnya masa berladang. Upacara Adat Naik Dango juga dipercaya memiliki manfaat dari segi sosial yakni, dapat mempererat hubungan persaudaraan.

Saat ini, upacara Naik Dango tidak hanya berisi kegiatan doa semata, melainkan diisi acara-acara yang menarik seperti, tarian-tarian dan bahkan pemilihan putra putri daerah. Tujuannya selain memanjatkan doa, juga diharapkan dapat mempererat tali persaudaraan dan juga mengenalkan budaya Naik Dango ke masyarakat lainnya. Tradisi Adat Naik Dango juga dapat dijadikan sebagai sarana wisata sehingga budaya yang ada di Kalimantan semakin dikenal luas. Yohanes (Pardosi, 2017) memaparkan bahwa dengan pelaksanaan Upacara Adat Naik Dango dapat meningkatkan peran serta masyarakat untuk pelestarian alam, lingkungan, dan budaya. Ranubaya (2016) menuturkan bahwa dalam kemasan modern, tradisi Naik Dango berisi berbagai acara adat yakni, kesenian tradisional, pameran berbagai bentuk kerajinan, dan sebagainya. Hal ini menyebabkan tradisi Naik Dango terlihat lebih seperti pesta adat dari pada upacara ritual. Meskipun demikian, inti dari dilaksanakannya upacara Naik Dango tetap ada. Mencermati perkembangan makna dari Upacara Adat Naik Dango, maka seiring perkembangan jaman nantinya tidak menutup kemungkinan ada penambahan makna baru. Hal ini selaras dengan perkembangan masyarakat yang beriringan dengan perkembangan jaman. Untuk menghindari pergeseran makna, maka pemahaman akan upacara adat harus tetap melekat bagi generasi penerus pada Suku Dayak Kanayant. Hal ini dimaksudkan agar generasi muda sekarang tidak meninggalkan budaya yang ditinggalkan oleh nenek moyang tak terkecuali Upacara Adat Naik Dango.

Upaya untuk dapat memahami, mengerti dan ikut melestarikan tradisi adat Naik Dango dibutuhkan pemahaman akan makna dari terselenggaranya upacara adat ini. Pada pelaksaannya, para pemuda yang tergolong dalam Dayak Kanayant turut memberikan kontribusi. Namun, keterlibatan mereka dalam Upacara Adat Naik Dango tentunya perlu diimbangi dengan pemahaman yang 
tinggi terhadap tradisi ini, sehingga tradisi ini tidak berakhir sebagai pesta adat semata, tetapi makna dari pelaksanaan Upacara Adat Naik Dango tetap ada. Sebagai langkah awal untuk mengenali tingkat pemahaman pemuda yang tergolong sebagai Dayak Kanayant, maka perlu dilakukan analisis tingkat pemahaman pada generasi muda di lingkungan Sekolah Tinggi llmu Manajemen Shanti Bhuana. Perguruan tinggi ini masih tergolong baru dan terletak di wilayah perbatasan negara Indonesia (Sadewo, 2018). Penelitian ini dapat memberikan gambaran tentang pemahaman generasi muda terhadap Upacara Adat Naik Dango khususnya mahasiswa STIM Shanti Bhuana. Hasil penelitian ini diharapkan dapat memberi manfaat positif bagi perkembangan Upacara Adat Naik Dango.

\section{METODE}

Penelitian ini termasuk penelitian kualitatif deskriptif dengan fokus untuk mengukur tingkat pemahaman Upacara Adat Naik Dango pada generasi muda subsuku Dayak Kanayant. Populasi dipilih di lingkungan Sekolah Tinggi IImu Manajemen (STIM) Shanti Bhuana Bengkayang dengan sampel adalah putra-putri subsuku Dayak Kanayant.

Pengukuran pemahaman mahasiswa STIM Shanti Bhuana yang merupakan bagian dari masyarakat Dayak Kanayant terhadap Upacara Adat Naik Dango dilakukan dengan penilaian dari angket yang telah disebar. Studi literatur dan wawancara tak terstruktur pada tokoh masyarakat yang berkedudukan sebagai "Tumenggung Binua" juga dilakukan untuk memperoleh data pendukung penelitian.

Studi literatur dilakukan untuk memperoleh kajian mengenai Upacara Adat Naik Dango serta dijadikan bahan rujukan dalam menyusun kuesioner. Kuesioner yang telah disusun digunakan untuk mendapat gambaran pemahaman responden terkait Upacara Naik Dango. Kuesioner ini terdiri dari 20 butir pernyataan mengenai Upacara Adat Naik Dango. Pernyataan tersebut dibagi menjadi 3 aspek yakni (1) pemahaman terhadap pengertian tentang Upacara Adat Naik Dango; (2) makna dari pelaksanaan Upacara Adat Naik Dango; (3) fungsi dilaksanakannya Upcara Adat Naik Dango. Berikut kisi-kisi dari kuesioner tersebut.

Tabel 1 Kisi-Kisi Kuesioner Pemahaman Upacara Adat Naik Dango

\begin{tabular}{|c|c|c|c|}
\hline No & Variabel & $\begin{array}{l}\text { Nomor } \\
\text { Item }\end{array}$ & $\begin{array}{c}\text { Jumlah } \\
\text { Item }\end{array}$ \\
\hline 1 & $\begin{array}{l}\text { Arti Upacara } \\
\text { Adat Naik } \\
\text { Dango }\end{array}$ & $\begin{array}{l}1,6,9 \\
10,11 \\
15,16\end{array}$ & 7 \\
\hline 2 & $\begin{array}{l}\text { Makna } \\
\text { Pelaksanaan } \\
\text { Upacara Adat } \\
\text { Naik Dango }\end{array}$ & $\begin{array}{l}3,4,5 \\
17,18 \\
19,20\end{array}$ & 7 \\
\hline 3 & $\begin{array}{l}\text { Fungsi } \\
\text { Upacara Adat } \\
\text { Naik Dango }\end{array}$ & $\begin{array}{c}2,7,8 \\
12,13 \\
14\end{array}$ & 6 \\
\hline & Total Item & \multicolumn{2}{|c|}{20} \\
\hline
\end{tabular}

\section{HASIL DAN PEMBAHASAN}

Pemahaman mahasiswa STIM Shanti Bhuana terkait Upacara Adat Naik Dango yang diukur melalui kuesioner secara garis besar dipaparkan sebagai berikut.

Tabel 2. Presentase Pemahaman Mahasiswa Terhadap Upacara Naik Dango

\begin{tabular}{clc}
\hline No & \multicolumn{1}{c}{ Variabel } & Presentase \\
\hline 1 & $\begin{array}{l}\text { Arti Upacara Naik } \\
\text { Dango }\end{array}$ & $68 \%$ \\
2 & $\begin{array}{l}\text { Makna Pelaksanaan } \\
\text { Upacara Adat Naik } \\
\text { Dango }\end{array}$ & $94 \%$ \\
3 & $\begin{array}{l}\text { Fungsi Upacara } \\
\text { Adat Naik Dango }\end{array}$ \\
& $80 \%$ \\
\hline
\end{tabular}




\begin{abstract}
Rata-Rata (\%)
$81 \%$

Rincian persentase tiap pernyataan terlampir.

Secara garis besar, tabel diatas menunjukkan bahwa pemahaman mahasiswa tentang Upacara Adat Naik Dango tergolong cukup baik. Namun, apabila dilihat secara rinci berdasarkan variabel yang diukur, maka terdapat perbedaan tingkat pemahaman. Pada variabel pertama yakni, Arti Upacara Naik Dango di mana pada bagian ini mencakup definisi dan sejarah menunjukkan bahwa kemampuan mahasiswa dalam bidang ini masih tergolong kurang, sedangkan pada indikator Makna Pelaksaan Upacara Adat Naik Dango, pemahamannya baik, dan pada Indikator Fungsi Upacara Adat Naik Dango tingkat pemahamannya cukup baik. Berikut dijabarkan penjelasan dari tiap variabel.
\end{abstract}

\section{a. Arti Naik Dango}

Tradisi Naik Dango merupakan tradisi adat di mana suku Dayak Kanayant melakukan ritual memanjatkan doa kepada sang Pencipta atas panen yang telah dilakukan.

Berdasarkan analisis data yang diperoleh dari subjek penelitian setelah diberikan 7 pertanyaan terkait pemahaman pada arti Upacara Naik Dango, jawaban mereka cukup bervariasi; tidak semua pemuda yang berasal dari suku Dayak Kanayant pada kenyataannya memahami arti Naik Dango dengan mendalam. Tingkat pemahaman terendah mahasiswa STIM Shanti Bhuana berada pada pemahaman akan sejarah Upacara Adat Naik Dango. Sebagian besar responden yakni, 20 orang dari 30, beranggapan bahwa Upacara Adat Naik Dango dilakukan oleh seluruh suku Dayak yang ada di Kalimantan. Pemahaman ini berbeda dengan sejarah Upacara Adat Naik Dango sebagaimana diungkapkan oleh (Ivo,
2001) dan (Ranubaya, 2016). Terjadinya pergeseran pemahaman di kalangan pemuda yakni, mahasiswa STIM Shanti Bhuana dipengaruhi oleh adanya Upacara Adat yang mirip Upacara Adat Naik Dango, tetapi nama berbeda.

Selain itu, pembelajaran budaya belum diberikan. Hal ini dapat terlihat dari belum adanya mata pelajaran khusus yang mempelajari sejarah maupun budaya adat Kalimantan. Hal senada dating dari Tumenggung Binua yang menuturkan bahwa belum ada pendidikan khusus yang mengajarkan sejarah budaya dan adat dari suku Dayak. Terlebih lagi buku-buku yang menuliskan sejarah Adat Naik Dango sebagai buku pembelajaran belum ada.

Secara garis besar pemahaman akan definisi Upacara Adat Naik Dango tergolong cukup baik. Artinya, masih ada generasi muda dari mayarakat Dayak Kanayant yang benar-benar memahami arti dari Naik Dango. Pemahaman ini ditunjukkan dari setiap jawaban terhadap pertanyaan yang diberikan. Pemahaman tersebut sesuai dengan pendapat dari (Ranubaya, 2016) bahwa tradisi Naik Dango sebagai upacara adat untuk memperingati kegiatan panen padi atau pesta padi sebagai ungkapan syukur masyarakat Dayak Kanayant kepada sang Pencipta terhadap hasil panen padi yang telah diperoleh. Lebih lanjut dijelaskannya bahwa melalui upacara Naik Dango, suku Dayak Kanayant dapat merefleksikan kegiatan yang telah dilakukan dan sekaligus memanjatkan doa kepada Sang Pencipta agar hasil panen berikutnya dapat lebih baik, serta memohon dihindarkan dari segala bencana dan malapetaka.

\section{b. Makna Pelaksanaan Upacara Adat Naik Dango}

Pada aspek ini dibahas mengenai pemahaman mahasiswa terhadap 
makna pelaksanaan dari upacara Naik Dango. Untuk itu, diberikan 7 pertanyaan yang berisi tentang makna dari pelaksanaan upacara Naik Dango. Berdasarkan data yang diperoleh, 28 orang dari 30 orang yang menjadi subjek penelitian menuturkan bahwa upacara ini memang memiliki makna ungkapan syukur kepada Tuhan atas panen padi yang dilakukan. Ungkapan syukur ini diwujudkan dalam doa-doa pada ritual dalam Upacara Adat Naik Dango. Hal ini selaras dengan temuan dari penelitian yang dilakukan oleh Kiki (2019) bahwa dalam simpulan hasil penelitiannya Upacara Adat Naik Dango pada masyarakat Dayak Kanayant dapat dimaknai sebagai ungkapan syukur kepada Tuhan atas limpahan berkat dari panen padi, sekalipun tidak hanya sebatas itu. Ungkapan ini juga ditunjukkan atas berkat kesehatan, perlindungan dalam bekerja, terhindar dari bencana, serta atas rejeki yang diperoleh.

Perkembangan jaman juga turut mempengaruhi prosesi ritual dalam Upacara Adat Naik Dango. Untuk itu, dilakukan analisis terhadap bagaimana generasi muda masyarakat Dayak Kanayant memaknai Upacara Naik Dango beserta perkembangannya. Hasil penelitian ini menunjukkan bahwa seluruh subjek penelitian mengemukakan dalam Upacara Adat Naik Dango yang dilakukan sekarang ini telah mengalami perkembangan dengan adanya kegiatan-kegiatan kesenian lainnya seperti tari-tarian, ataupun pentas seni lainnya. Hal ini tentu saja selaras dengan pendapat dari (Ranubaya, 2016) yang menyatakan bahwa seiring dengan perkembangan jaman, tradisi upacara Naik Dango mengalami perkembangan dengan disisipkannya kesenian-kesenian lainnya. Hal ini membuat upacara Naik Dango tidak hanya berisi ritual doa-doa semata, namun ada unsur kesenangan yang ditunjukan lewat tari-tarian dan kesenian lainnya. Tradisi ini dilakukan setiap tahun dan terbuka untuk umum sehingga Upacara Adat Naik Dango dapat menjadi sarana pariwisata.

\section{c. Fungsi dan Tujuan Pelaksanaan Upacara Adat Naik Dango}

Pada aspek ini akan dilihat pemahaman genersi muda masyarakat Dayak Kanayant mengenai fungsi dan tujuan dari pelaksanaan Naik Dango. Pada aspek ini terdapat 6 sub aspek yang digolongkan dalam fungsi dan tujuan pelaksanaan Naik Dango. Hasil analisis menunjukkan bahwa fungsi dan tujuan dari Upacara Adat Naik Dango secara garis besar dipahami dengan baik oleh subjek yang diteliti. Namun, pada bagian pemahaman responden terkait kepercayaan akan bencana serta berkat yang diperoleh dari dilakukannya Upacara Adat Naik Dango berbeda dengan pendapat Priskila (2010). Menurutnya, melalui upacara ini dipercaya bahwa masyarakat akan mendapat berkat dan terhindar dari bencana. Seiring perkembangan jaman serta masuknya unsur agama di masyarakat tentu turut mengubah pemahaman masyarakat terhadap nasib manusia. Mahasiswa STIM Shanti Bhuana yang saat ini berusia rata-rata 18 tahun berpandangan bahwa nasib sial tergantung dari tingkat kepercayaan masing-masing individu.

Sebagian besar subjek penelitian yang merupakan generasi muda masyarakat Dayak Kanayant meyakini bahwa upacara adat ini selain memiliki makna untuk acara ritual adat, juga untuk sarana wisata. Seiring perkembangan jaman, upacara ini tidak tertutup untuk masyarakat Dayak Kanayant semata melainkan dapat disaksikan oleh seluruh lapisan masyarakat meskipun berbeda suku dan budaya, namun dalam pelaksanaanya tetap menjadi milik 
masyarakat Dayak Kanayant. Selain itu, hasil penelitian juga menunjukkan bahwa Upacara Adat Naik Dango juga dipercaya dapat menjadi sarana pemersatu masyarakat khususnya pada masyarakat Dayak Kanayant. Adanya kegiatan tari-tarian juga diyakini mampu melestarikan sekaligus mengenalkan budaya dari masyarakat Dayak Kanayant.

Pada simpulan yang diberikan Kiki (2019) menekankan pada keyakinan masyarakat Dayak Kanayant terhadap adanya Tuhan. Namun, fakta lain dalam penelitian ini menunjukkan bahwa pemahaman akan hal terkait kepercayaan akan pelaksanaan Upacara Naik Dango berbeda dengan temuan dari penelitan tersebut. Hal ini ditunjukkan dengan rendahnya tingkat kepercayaan subjek yang diteliti akan keyakninan tertimpa bencana jika Upacara Naik Dango tidak dilakukan secara semestinya. Masyarakat Dayak Kanayant mempercayai bahwa apabila Upacara Adat Naik Dango dilakukan namun masih ada tempat yang belum usai panen, maka akan menimbulkan kesialan seperti hasil panen yang akan cepat habis, dan menurunnya hasil panen pada panen berikutnya, namun kepercayaan ini justru telah mengalami penurunan. Hal ini mungkin saja terjadi dengan berbagai faktor yang mempengaruhi seiring perkembangan jaman.

\section{KESIMPULAN}

Berdasarkan hasil penelitian dan pembahasan maka diketahui bahwa secara keseluruhan kemampuan generasi muda masyarakat Dayak Kanayant dalam memahami Upacara Adat Naik Dango berada pada kategori cukup baik. Mayoritas generasi muda masyarakat Dayak Kanayant yang dijadikan responden menyadari bahwa upacara adat ini secara khusus dilakukan untuk ungkapan syukur atas panen padi atau pesta padi kepada sang Pencipta terhadap hasil panen padi yang telah diperoleh. Selain itu pelaksanaan dari Upacara Naik Dango juga telah mengalami perkembangan yakni dengan disisipinya berbagai kesenian adat. Hal ini juga turut mempengaruhi tujuan dari Upacara Adat Naik Dango yakni tidak sebatas ungkapan syukur kepada Pencipta namun juga digunakan untuk mempererat hubungan antar masyarakat.

\section{REKOMENDASI}

Berdasarkan hasil penelitian yang telah dipaparkan secara garis besar menunjukkan generasi muda masyarakat Dayak Kanayant menyadari arti, makna, dan tujuan dari Upacara Adat Naik Dango. Namun, dalam beberapa aspek pemahaman tersebut perlu diperdalam dan diperkuat sehingga tidak mudah luntur dengan adanya perkembangan jaman. Mengingat Upacara Adat Naik Dango yang dilakukan saat ini telah mengalami perkembangan maka tidak menutup kemungkinan akan terjadi perkembangan berikutnya. Oleh sebab itu pemahaman mendalam perlu dimiliki setiap masyarakat Dayak Kanayant khususnya pada generasi muda. Pemberian pendidikan terkait budaya adat perlu dilakukan. Pendidikan adat budaya dapat diberikan dalam bentuk muatan lokal di setiap sekolah, pembuatan bahan ajar berdasarkan kajian muatan lokal terkhusus adat dan budaya masyakat dayak yang belum ada juga diperlukan dalam rangka menunjang pembelajaran dengan kajian ini, sehingga pemahaman akan budaya tetap ada dan tidak mudah terkikis oleh perkembangan jaman. Pemerintah dareah setempat juga perlu untuk tetap melestarikan adat dan budaya masyarakat Dayak dengan membuat kebijakan mengenai muatan adat dan budaya masyarakat Dayak masuk ke 
dalam pembelajaran pendidikan di sekolah, baik di sekolah dasar, sekolah menengah pertama, sekolah menengah atas ataupun di pendidikan tinggi. Pemerintah daerah juga dapat mengadakan lomba literasi penulisan adat dan budaya masyarakat Dayak secara rutin.

\section{UCAPAN TERIMA KASIH}

Terima kasih disampaikan kepada segenap mahasiswa STIM Shanti Bhuana program studi manajemen dan program studi kewirausahaan yang telah membantu dalam pelaksanaan penelitian ini hingga selesai.

\section{DAFTAR PUSTAKA}

Ivo, H. (2001). Gawai Dayak dan Fanatisme Rumah Panjang sebagai Penelusuran Identitas. Humaniora, 13(3). https://doi.org/10.22146/jh.v13i3.7 36

Kiki, E. (2019). Makna Tradisi Naik Dango Bagi Masyarakat Suku Dayak Kanayatn di Kabupaten Sambas Provinsi Kalimantan Barat. Universitas Muhammadiyah Malang.

Mintosih, S., \& Widiyanto, Y. S. (1997). Tradisi dan Kebiasaan Makan Pada Masyarakat Tradisional di Kalimantan Barat (1st ed.). Jakarta: Proyek Pengkajian dan Pembinaan Nilai-nilai Budaya, Direktorat Sejarah dan Nilai Tradisional, Direktorat Jenderal Kebudayaan, Departemen Pendidikan dan Kebudayaan.

Pardosi, A. (2017, April). Gubernur Kalbar Buka Naik Dango XXXII di Ngabang. Tribun Pontianak. Retrieved from https://pontianak.tribunnews.com/ 2017/04/26/gubernur-kalbar-bukanaik-dango-xxxii-di-ngabang
Priskila, H. (2010). Tradisi Naik Dango Suku Dayak Kanayatn: Kajian Asal Usul, Proses Ritual, Fungsi dan Nilai. Universitas Sanata Dharma.

Ranubaya, F. A. (2016). Budaya Naik Dango Suku Dayak Kanayatn. Retrieved from http://dayaktalino.blogspot.com/20 16/05/budaya-naik-dango-sukudayak-kanayatn.html

Sadewo, Y. D. (2018). Hambatan dan Tantangan Program Studi Kewirausahaan di Wilayah Perbatasan. MABIS, 8(1).

Saryana. (2003). Upacara Adat Dan Rumah Adat: Suku Dayak Dan Melayu Kalimantan Barat. Pontianak: Romeo Grafika.

Wina, P., \& Habsari, N. T. (2017). Peran Perempuan Dayak Kanayatn Dalam Tradisi Upacara Naik Dango (Studi Di Desa Padang Pio Kecamatan Banyuke Hulu Kabupaten Landak Kalimantan Barat). Agastya: Jurnal Sejarah Dan Pembelajarannya, 7(01), 104-126. https://doi.org/10.25273/ajsp.v7i01 .1063 


\section{LAMPIRAN}

\section{Kuesioner Adat Naik Dango}

Nama

Prodi

Hari/Tanggal :

\section{Petunjuk:}

a. Pilihlah salah satu jawaban yang sesuai dengan yang anda pahami dengan memberikan tanda centang $(\sqrt{ })$ pada kolom YA dan TIDAK yang disediakan.

b. Setiap jawaban anda tidak ada hubungannya dengan mata kuliah apapun sehingga jangan terpengaruh dengan jawaban teman-teman anda.

c. Isian angket ini tidak berpengaruh pada nilai tes/ IPK, maka anda diminta memberikan jawaban yang sejujurnya menurut pandangan anda.

d. Tanyakan pada dosen/pembimbing apabila ada pertanyaan yang kurang jelas.

\begin{tabular}{|c|c|c|c|}
\hline No & Pernyataan & YA & TIDAK \\
\hline 1. & $\begin{array}{l}\text { Upacara Adat Naik Dango merupakan ritual yang dilakukan usai } \\
\text { panen padi }\end{array}$ & & \\
\hline 2. & $\begin{array}{l}\text { Upacara Adat Naik Dango merupakan ritual yang dilakukan sebagai } \\
\text { ungkapan syukur atas panen padi yang telah dilakukan }\end{array}$ & & \\
\hline 3. & $\begin{array}{l}\text { Upacara Adat Naik Dango tidak hanya dilakukan seusai panen padi } \\
\text { saja melainkan setiap kali panen jagung dan sayuran lainnya }\end{array}$ & & \\
\hline 4. & Upacara Adat Naik Dango dilakukan dari setiap menanam padi & & \\
\hline 5. & $\begin{array}{l}\text { Dalam Upacara Adat Naik Dango, hanya ada perayaan berupa tari- } \\
\text { tarian tanpa ada doa dan ucapan syukur }\end{array}$ & & \\
\hline 6. & $\begin{array}{l}\text { Upacara Adat Naik Dango dilakukan oleh semua suku dayak yang } \\
\text { ada di Kalimantan }\end{array}$ & & \\
\hline 7. & $\begin{array}{l}\text { Upacara Adat Naik Dango dilakukan agar tidak terjadi hujan saat } \\
\text { acara panen berlangsung }\end{array}$ & & \\
\hline 8. & Upacara Adat Naik Dango menjadi sarana pemersatu masyarakat & & \\
\hline 9. & Upacara Adat Naik Dango dilakukan oleh suku Dayak Kanayant & & \\
\hline 10. & Upacara Adat Naik Dango sudah dimulai dari tahun 1985 & & \\
\hline 11. & $\begin{array}{l}\text { Di wilayah lain di Kalimantan terdapat ritual sejenis Naik Dango } \\
\text { namun memiliki sebutan yang berbeda-beda }\end{array}$ & & \\
\hline 12. & $\begin{array}{l}\text { Upacara Adat Naik Dango merupakan ritual doa agar panen pada } \\
\text { tahun mendatang juga melimpah dan dibebaskan dari hama dan } \\
\text { bencana }\end{array}$ & & \\
\hline 13. & $\begin{array}{l}\text { Upacara Adat Naik Dango merupakan ritual setelah panen yang } \\
\text { dilakukan untuk memanjatkan doa supaya hasil panen berikutnya } \\
\text { melimpah }\end{array}$ & & \\
\hline 14. & Upacara Adat Naik Dango juga dapat menjadi sarana wisata & & \\
\hline 15. & $\begin{array}{l}\text { Dalam tradisi nenek moyang Dayak Kanayant, Naik Dango di awali } \\
\text { dengan pertemuan antar penduduk yang dilakukan seusai panen. }\end{array}$ & & \\
\hline
\end{tabular}




\begin{tabular}{|c|c|}
\hline 16. & $\begin{array}{l}\text { Sampai saat ini Upacara Adat Naik Dango hanya dilakukan di } \\
\text { kampung saja }\end{array}$ \\
\hline 17. & $\begin{array}{l}\text { Upacara Adat Naik Dango hanya ritual adat biasa yang tidak } \\
\text { mengandung makna apa-apa }\end{array}$ \\
\hline 18. & $\begin{array}{l}\text { Sekarang ini Upacara Adat Naik Dango dapat diselingi kegiatan } \\
\text { tradisional dan kegiatan menarik lainnya }\end{array}$ \\
\hline 19. & $\begin{array}{l}\text { Upacara Adat Naik Dango merupakan acarra yang memiliki } 3 \text { aspek } \\
\text { pokok yaitu aspek kehidupan agraris, aspek religius, dan aspek } \\
\text { kehidupan kekeluargaan solidaritas serta persatuan }\end{array}$ \\
\hline 20. & $\begin{array}{l}\text { Makna terdalam dari Upacara Adat Naik Dango adalah ucapan } \\
\text { syukur atas panen padi yang telah dilakukan }\end{array}$ \\
\hline
\end{tabular}

\section{Rekap Pemahaman Mahasiswa Tentang Upacara Naik Dango}

\begin{tabular}{|c|c|c|}
\hline Indikator & Pernyataan & $(\%)$ \\
\hline \multirow{7}{*}{$\begin{array}{l}\text { Arti Upacara } \\
\text { Adat Naik } \\
\text { Dango }\end{array}$} & $\begin{array}{l}\text { Upacara Adat Naik Dango merupakan ritual yang dilakukan usai } \\
\text { panen padi }\end{array}$ & $97 \%$ \\
\hline & $\begin{array}{l}\text { Upacara Adat Naik Dango dilakukan oleh semua suku dayak yang } \\
\text { ada di Kalimantan }\end{array}$ & $33 \%$ \\
\hline & Upacara Adat Naik Dango dilakukan oleh suku Dayak Kanayant & $73 \%$ \\
\hline & Upacara Adat Naik Dango sudah dimulai dari tahun 1985 & $40 \%$ \\
\hline & $\begin{array}{l}\text { Di wilayah lain di Kalimantan terdapat ritual sejenis Naik Dango } \\
\text { namun memiliki sebutan yang berbeda-beda }\end{array}$ & $83 \%$ \\
\hline & $\begin{array}{l}\text { Dalam tradisi nenek moyang Dayak Kanayant, Naik Dango diawali } \\
\text { dengan pertemuan antar penduduk yang dilakukan seusai panen. }\end{array}$ & $80 \%$ \\
\hline & $\begin{array}{l}\text { Sampai saat ini Upacara Adat Naik Dango hanya dilakukan di } \\
\text { kampung saja }\end{array}$ & $73 \%$ \\
\hline \multirow{7}{*}{$\begin{array}{l}\text { Makna } \\
\text { Pelaksanaan } \\
\text { Upacara Adat } \\
\text { Naik Dango }\end{array}$} & $\begin{array}{l}\text { Upacara Adat Naik Dango tidak hanya dilakukan seusai panen padi } \\
\text { saja melainkan setiap kali panen jagung dan sayuran lainnya }\end{array}$ & $93 \%$ \\
\hline & Upacara Adat Naik Dango dilakukan dari setiap menanam padi & $80 \%$ \\
\hline & $\begin{array}{l}\text { Dalam Upacara Adat Naik Dango, hanya ada perayaan berupa tari- } \\
\text { tarian tanpa ada doa dan ucapan syukur }\end{array}$ & $97 \%$ \\
\hline & $\begin{array}{l}\text { Upacara Adat Naik Dango hanya ritual adat biasa yang tidak } \\
\text { mengandung makna apa-apa }\end{array}$ & $97 \%$ \\
\hline & $\begin{array}{l}\text { Sekarang ini Upacara Adat Naik Dango dapat diselingi kegiatan } \\
\text { tradisional dan kegiatan menarik lainnya }\end{array}$ & $100 \%$ \\
\hline & $\begin{array}{l}\text { Upacara Adat Naik Dango merupakan acara yang memiliki } 3 \text { aspek } \\
\text { pokok yaitu aspek kehidupan agraris, aspek religius, dan aspek } \\
\text { kehidupan kekeluargaan solidaritas serta persatuan }\end{array}$ & $93 \%$ \\
\hline & $\begin{array}{l}\text { Makna terdalam dari Upacara Adat Naik Dango adalah ucapan } \\
\text { syukur atas panen padi yang telah dilakukan }\end{array}$ & $93 \%$ \\
\hline \multirow{3}{*}{$\begin{array}{l}\text { Fungsi } \\
\text { Upacara Adat } \\
\text { Naik Dango }\end{array}$} & $\begin{array}{l}\text { Upacara Adat Naik Dango merupakan ritual yang dilakukan } \\
\text { sebagai ungkapan syukur serta permohonan atas panen padi yang } \\
\text { telah dilakukan }\end{array}$ & $93 \%$ \\
\hline & $\begin{array}{l}\text { Upacara Adat Naik Dango dilakukan agar tidak terjadi hujan saat } \\
\text { acara panen berlangsung }\end{array}$ & $90 \%$ \\
\hline & Upacara Adat Naik Dango menjadi sarana pemersatu masyarakat & $100 \%$ \\
\hline
\end{tabular}




\begin{tabular}{|l|l|c|}
\hline & $\begin{array}{l}\text { Upacara Adat Naik Dango merupakan ritual doa agar panen pada } \\
\text { tahun mendatang juga melimpah dan dibebaskan dari hama dan } \\
\text { bencana }\end{array}$ & $23 \%$ \\
\cline { 2 - 3 } $\begin{array}{l}\text { Upacara Adat Naik Dango merupakan ritual setelah panen yang } \\
\text { dilakukan untuk memanjatkan doa supaya hasil panen berikutnya } \\
\text { melimpah }\end{array}$ & $80 \%$ \\
\cline { 2 - 3 } & \begin{tabular}{l} 
Upacara Adat Naik Dango juga dapat menjadi sarana wisata \\
\multicolumn{1}{|c|}{ Rata-Rata Persentase }
\end{tabular} & $\mathbf{8 1 \%} \%$ \\
\hline
\end{tabular}

